\title{
LOCAL GOVERNMENT EXPLAINED
}


By the same author

Municipal Engineering Practice Outdoor Recreation and the Urban Environment

Planned Expansion of Country Towns (published by George Godwin)

Civil Engineering Quantities

Civil Engineering Specification

Building Quantities Explained

Building Economics

Building Technology

Building Maintenance 


\title{
LOGAL GOVERNMENT EXPLAINED
}

\author{
Ivor H. Seeley \\ B.Sc., M.A., Ph.D., F.R.I.C.S., C.Eng., \\ F.I.Mun.E., F.I.Q.S., M.I.O.B. \\ Head of the Department of Surveying \\ and Dean of the School of Environmental Studies, \\ Trent Polytechnic, Nottingham
}


(c) Ivor H. Seeley 1978

Softcover reprint of the hardcover 1st edition 1978 978-0-333-22355-0

All rights reserved. No part of this publication may be reproduced or transmitted, in any form or by any means, without permission.

First published 1978 by

THE MACMILLAN PRESS LTD

London and Basingstoke

Associated companies in Delhi Dublin

Hong Kong Johannesburg Lagos Melbourne

New York Singapore and Tokyo

British Library Cataloguing in Publication Data

Seeley, Ivor Hugh

Local government explained.

1. Local government - Great Britain

I. Title

352.041

JS 3025

ISBN 978-0-333-22357-4

ISBN 978-1-349-15961-1 (eBook)

DOI 10.1007/978-1-349-15961-1

This book is sold subject to the standard conditions of the Net Book Agreement.

The paperback edition of this book is sold subject to the condition that it shall not, by way of trade or otherwise, be lent, resold, hired out, or otherwise circulated without the publisher's prior consent in any form of binding or cover other than that in which it is published and without a similar condition including this condition being imposed on the subsequent purchaser. 
This book is dedicated to the councillors of the former urban district of Haverhill and the former rural district of Newport Pagnell, with whom I had the privilege to be associated as a chief officer. 


\section{CONTENTS}

List of Figures $\quad$ xi

List of Tables $\quad$ xi

Preface xiii

1. Historical Development of Local Government 1 Early developments: Mediaeval period, Tudor period, the eighteenth century; position in early nineteenth century: parishes, counties, boroughs, ad hoc authorities; early reform of local government; later developments (18801944): the need for reform, establishment of county councils, rationalisation of other levels of local government, growth of population, towns and transport, Local Government Act 1929, loss of functions to central government, increased central government control; main local authority functions: education, highways, public health, housing and town planning, police, municipal trading and other services; references

2. Winds of Change

Need for reform; immediate post-war developments: 1945

White Paper on Local Government, Local Government Boundary Commission; the Local Government Act 1958 and consequent developments; Royal Commission on Local Government in England, 1966-9: procedure, existing deficiencies, general principles formulated by Commission, Commission's approach, Commission's proposals, reaction to Commission's report; local government in London; references

3. Local Government Structure since 1974

Reorganisation proposals; Local Government Act 1972; transitional arrangements; functions of new local authorities: discharge of functions, allocation of functions, county councils, shared functions, additional functions of metropolitan districts, district councils, parish and community 
councils, division of responsibilities; problems in operation of latest local government structure; further transfer of functions from local government; references

\section{Local Government Procedures}

Constitution of local authorities; election qualifications; election procedures: local government franchise, conduct of elections, casual vacancies; alteration of local government areas; councils and their meetings; management in local government; committee structure: functions of committees, types of committee, composition and size of committees, control of committees by council, co-option, committee arrangements, advantages and disadvantages of the committee system, later developments; councillors: characteristics, qualities, functions, pay and allowances; party politics in local government; officers: principal responsibilities, statutory officers; relationship of members and officers; corruption; references

\section{Management Structures and Techniques}

The concept of corporate management; background to corporate management: Maud Report, Bains Report; new committee structures: reasons for change, new committee arrangements, policy and resources committee; chief executive; management team; corporate management in action: new local authority structures, county council structures, district council structures, the application of corporate management; management techniques: management services, employment of private consultants, LAMSAC, planning, programming and budgeting systems, work study, organisation and methods, operational research, network analysis, cost-benefit analysis, use of computers; departmental organisation: departmental structures, role of chief officers; references

\section{Local Government Administration}

Committee procedures: standing orders, general arrangements at meetings, public access to meetings, appointment of committee members, chairmen of councils and committees, programme of meetings; agenda; reports: general requirements of reports; preparations for and conduct of meetings: preliminary preparations, attendance of members and quorum, conduct of meetings, motions, notes of meetings; minutes: purposes, preparation, action on 
minutes; local government staffing: the local government service, conditions of employment, personnel management, superannuation, conditions of service; recruitment and training: recruitment, induction, training, Local Government Training Board; staff development: selection, promotion and career prospects, manpower planning; references

7. Local Government Finance

Financial needs of local authorities: budgets; main sources of local government income; rating: nature and method of operation, valuations and valuation lists, merits and demerits of rating, rate rebates and other forms of assistance, reforms; financial relations with central government: grants, subsidies, loans; financial problems of local authorities in the mid-1970s; alternative sources of local authority income: local income tax, local sales tax, local employment or payroll tax, motor fuel duty, motor vehicle duties, super-rating, surcharges on rates for earning non-householders, site value rating, rating of agriculture, lotteries; Layfield Report and the future in local government finance; references

8. Powers and Responsibilities of Local Authorities

General powers: Statutory Instruments; doctrine of ultra vires; judicial control; Acts of Parliament: public Acts, private Acts, Clauses Acts; Orders; bye-laws: nature and scope, making of bye-laws, confirmation of bye-laws, model bye-laws, validity of bye-laws, relaxation and reapproval of bye-laws; legal status of local authorities; local authorities in litigation; Commissioners for Local Administration; references

9. Central Government Control

Central and local government relationships; legislative control; administrative control: general powers, directions, regulations, bye-laws, supervision, inspection, other ministerial actions and requirements, central-local communications; financial control: loans, grants; district audit: nature and form of audit, appointment and duties of auditors, district audit procedure, advantages of district audit; appeals, default powers and settlement of disputes; control through inspection: inspection of services, inspectorate and inquiries; approval of schemes; effect of central control; references 
10. Local Government Needs and the Future

Public relations: communication, local press, public relations officers, Commissioners for Local Administration; co-operation between authorities: combined sports centres, expanding towns, shared and inter-related functions; neighbourhood councils and other pressure or voluntary groups; regionalism and devolution; the impact of reorganisation: the changed situation, effect of party politics, corporate management, officer/member relationships; corruption; local government finance; central/ local government relationships; major problems facing local government: finance and staffing, housing, town and country planning, inner-city renewal, other services; what of the future? references

Index 


\section{LIST OF FIGURES}

1. Local government structure - England and Wales, 18991974 (London, 1899-1963)

2. Local government - London

3. Local government - England and Wales: county boundaries since 1974

4. Revised local government structure - England and Wales

5. Committee structure - non-metropolitan county (Bains Committee proposals)

6. Departmental structure - larger non-metropolitan district (Bains Committee proposals)

7. Member involvement - Suffolk County Council

8. Main management processes cycle

\section{LIST OF TABLES}

1. Population ranges for each type of authority in 1973

2. Division of English local government functions 42

3. Sources of local revenue 116 


\section{PREFACE}

This book is aimed primarily at students of local government, whatever their discipline, but may also be of value to new and prospective councillors and officers, and to members of the public who are interested in the workings of local government.

After delving into the foundations of local government, the changes to the local government structure and functions are examined, followed by an analysis of operative procedures and techniques. The sources of finance, their deficiencies and alternative arrangements are explored, together with the powers and responsibilities of local authorities and the form and extent of central government control. Finally, current local government needs are investigated and an eye directed at the future.

Most of my career has been spent in the local government service, including some six years as a chief officer. I am proud to have served an important branch of the public service which has done so much to improve the health, comfort, well-being and education of the citizens of this country.

Views diverge widely as to the optimum local government structure for the United Kingdom and it has, sadly, become a political issue. Present experience points to the undesirability of sharing functions between different tiers and of separating interrelated activities which ought desirably to be grouped within the same authority. Some flexibility is needed as a single framework cannot be applied effectively to the whole country. Finally, a proper balance must be achieved between efficiency and democracy.

Relationships between officers and members and between central and local government need to be deeply rooted in respect and understanding one for the other. Local government would benefit from greater freedom of action and increased scope for the exercise of initiative in responding to local needs and aspirations. If local authorities were merely to become the agents of central government, it would be the end of effective and democratic local government and the country would be the poorer for it.

The operation of the local government service is dependent upon thousands of devoted elected members, who give selflessly of their time and energy in the interests of the community. As local government activities become increasingly complex they draw ever more 
heavily upon councillors' time and it may become necessary in the future to pay salaries to some, if not all, councillors. Any corruption occurring in local government is given maximum publicity by the media, whereas the total number of serious cases of fraud or corruption is comparatively small, giving testimony to the integrity of the vast majority of people connected with the local government service, despite the many temptations they face.

The nineteen-seventies have seen a substantial increase in the degree of involvement of party politics in local government. Where all decisions are made by a political group outside council and committee meetings, with little or no opportunity for discussion or debate, healthy and democratic local government can easily be undermined.

The mid-nineteen-seventies have shown the vulnerability of local authorities in times of economic crisis, with such a high proportion of their funds obtained from central sources. The problem is accentuated by central government delegating new and costly activities to local authorities at the same time as it is reducing local government grants.

Improved and closer working arrangements between local authorities and the press are needed. Local authorities must allow ample access to the press and the public, while the press must endeavour to report accurately and fully. Local authorities have an important public relations function and should aim to keep the public well informed of their proposals, problems and achievements.

I would like to acknowledge the help I have received from NALGO Education Department in the supply of valuable information, the Local Government Chronicle and Clifford Smith, Chief Executive to Suffolk County Council, for supplying the basic data for Figure 7, and the Controller of Her Majesty's Stationery Office for permission to incorporate extracts from Government reports. For the legal background I have drawn freely upon the well established and authoritative works of C. A. Cross and W. O. Hart. Charles Hardwick of the Trent Polytechnic Library provided a wealth of supporting information and data.

Other fruitful sources of information were the numerous journals impinging upon local government, and particularly Local Government Chronicle, Local Government Review, Municipal Review, Local Government Studies, Public Finance and Accountancy and Local Government Annotations.

I am indebted to all the officers and councillors who over the years have given me the benefit of their views and experience, for which I have been much the richer and wiser. It is on occasions beneficial for the enthusiasm of officers to be moderated by experi- 
enced elected members, whose primary aim is to satisfy pressing local needs within the available resources.

Finally, I have used the term 'Minister' extensively to cover the Secretary of State for the Environment.

Nottingham

IVOR H. SEELEY

Autumn 1977 